\title{
Greywater Treatment by High Rate Algal Pond under Sahelian Conditions for Reuse in Irrigation
}

\author{
Ynoussa Maiga 1*, Masahiro Takahashi², Thimotée Yirbour Kpangnane Somda3, \\ Amadou Hama Maiga $^{3}$ \\ ${ }^{1}$ Laboratory of Microbiology and Microbial Biotechnology, University of Ouagadougou, Ouagadougou, \\ Burkina Faso \\ ${ }^{2}$ Environmental Engineering and Science, Hokkaido University, Sapporo-shi, Japan \\ ${ }^{3}$ Laboratory of Water Decontamination, Ecosystems and Health, International Institute for Water and \\ Environmental Engineering, Ouagadougou, Burkina Faso \\ Email: ynoussa.maiga@gmail.com, m-takaha@eng.hokudai.ac.jp, thimotekpangnane@yahoo.fr, \\ amadou.hama.maiga@2ie-edu.org
}

Received 11 August 2015; accepted 19 September 2015; published 22 September 2015

Copyright (C) 2015 by authors and Scientific Research Publishing Inc.

This work is licensed under the Creative Commons Attribution International License (CC BY). http://creativecommons.org/licenses/by/4.0/

(c) (i) Open Access

\section{Abstract}

High Rate Algal Pond (HRAP) was constructed and operated using a mixer device to investigate its capability in treating greywater for reuse in gardening. Physico-chemical and microbiological parameters were monitored. With a hydraulic retention time of 7.5 days and a solid retention time of 20 days, the average removal efficiencies (ARE) were $69 \%$ and $62 \%$ for $B D_{5}$ and COD respectively. The ARE for $\mathrm{NO}_{3}^{-}, \mathrm{NH}_{4}^{+}$and $\mathrm{PO}_{4}^{3-}$ were $23 \%, 52 \%$ and $43 \%$ respectively. The removal of suspended solids (SS) was unsatisfactory, which could be attributed to the low average algal settling efficiencies of $9.3 \%$ and $16.0 \%$ achieved after 30 and 60 minutes respectively. The ARE of fecal coliforms, Escherichia coli and enterococci were 2.65, 3.14 and 3.17 log units respectively. In view of the results, the HRAP technology could be adapted for greywater treatment in sahelian regions. However, further studies on the diversity of the algal species growing in the HRAP unit are necessary in order to increase the removal of SS. Hazards of a reuse of the effluents are discussed on the basis of the various qualitative parameters. The residual content of $E$. coli was varying from $<1$ to $1.77 \times 10^{4} \mathrm{CFU}$ per $100 \mathrm{~mL}$. Based on WHO guidelines for greywater reuse in irrigation, the effluents could be used for restricted irrigation (E. coli $<10^{5} \mathrm{CFU}$ per $100 \mathrm{~mL}$ ). Furthermore, the reuse potential is discussed on the basis of FAO guidelines using SAR (3.03 to 4.11), electrical conductivity ( 482 to $4500 \mu \mathrm{S} / \mathrm{cm})$ and $\mathrm{pH}$ values $(6.45$ to 8.6$)$.

*Corresponding author.

How to cite this paper: Maiga, Y., Takahashi, M., Somda, T.Y.K. and Maiga, A.H. (2015) Greywater Treatment by High Rate Algal Pond under Sahelian Conditions for Reuse in Irrigation. Journal of Water Resource and Protection, 7, 1143-1155. 
Keywords

Greywater Treatment, High Rate Algal Pond, Irrigation Reuse, Sahelian Region

\section{Introduction}

Wastewater reuse in irrigation has been reported worldwide [1] including in low-income arid and semi-arid countries, where water shortage has promoted the use of alternative sources. In Burkina Faso, treated and untreated wastewater are used in gardening and horticulture [1] [2], in spite of the health and environmental risks. Wastewater recycling for reuse in irrigation can have multiple benefits especially for low-income arid and semi-arid regions, since it can contribute to reducing water related diseases with increased possibilities for food production and increased employment opportunities for poor population. Due to the low levels of microorganisms, greywater which constitutes $50 \%$ to $80 \%$ of the total household wastewater [3], is receiving more and more attention. However, many different kinds of pathogen of fecal origin have been found in greywater [4]. Besides, irrigation with untreated greywater has been demonstrated to contribute to increased soil hydrophobicity [5] and levels of fecal bacteria in the soil [6]. Treatment methods that reduce the number of pathogens are thus necessary if greywater is to be used for vegetables irrigation. High Rate Algal Pond (HRAP) is one of the promising wastewater treatment technologies: it provides cost-effective and efficient treatment with minimal energy consumption and has considerable potential to upgrade oxidation ponds [7]. In addition, the algal biomass harvested from this treatment system could be converted to biofuels, biogas and bioethanol [8] [9]. Previous studies have reported wastewater treatment by HRAP system equipped with an air-lift [10] and a paddlewheel [11]. The present study deals with HRAP system operated with a mixer agitation system for greywater treatment under real sahelian conditions. Furthermore, to our knowledge, it is the first time to assess the operation of a HRAP system in Burkina Faso where more than 300 days per year can be expected to be sunny [12]. HRAP is characterized by their shallow depth and high algal productivity that can negatively impact the irrigated soil. Recycling gravity harvested algae could be a simple and effective operation strategy to maintain the dominance of readily settleable algal species, and enhance algal harvest by gravity sedimentation [11]. This consideration is particularly important when the treated water is intended for reuse in irrigation, since it minimizes the clogging of irrigated soil. Therefore, the experimental HRAP is equipped with an algal recycling system.

The purpose of this study was to evaluate the potential of a HRAP system operated with a mixer, to adequately treat greywater under sahelian climatic conditions for reuse in gardening. The specific objectives were to:

- Evaluate the efficiency of the HRAP in terms of greywater chemical pollutants removal;

- Evaluate the efficiency of the HRAP related to greywater microbial removal;

- Discuss the reuse potential of the treated greywater.

\section{Material and Methods}

\subsection{Experimental HRAP: Characteristics, Operation and Greywater Source}

Experiments were carried out using a pilot-scale single-loop race truck configuration HRAP treating greywater at the International Institute for Water and Environmental Engineering (2iE) campus of "Kamboinsé", Ouagadougou, Burkina Faso $(12.46 \mathrm{~N}, 1.55 \mathrm{~W})$. The HRAP had a surface area of $84.4 \mathrm{~m}^{2}$, a depth of $0.3 \mathrm{~m}$ and a total volume of $21.09 \mathrm{~m}^{3}$. The design characteristics are presented in Table 1.

The pond water was continuously mixed (from 6:00 am to 6:00 pm) by a mixer (Satake Model A640 SATAKE chemical Equipment) allowing a speed of water at the surface of $15 \mathrm{~m} / \mathrm{s}$. A top view of the pilot-scale HRAP is shown in Figure 1. Greywater was collected from a dormitory of 40 students at the 2iE campus of "Kamboinsé". Shower, laundry and washbasin greywater are discharged into a single outlet pipe from which, it flowed by gravity to the water receiving pond (RP) of the treatment unit (Figure 1). The greywater is pumped to the Imhoff tank (IT) using a peristaltic pump (Master flex Model 07591-55) at a flow rate of $2.8 \mathrm{~m}^{3} / \mathrm{day}$, the remaining greywater being discharged to the infiltration pond (IP) for infiltration. From IT, the greywater 


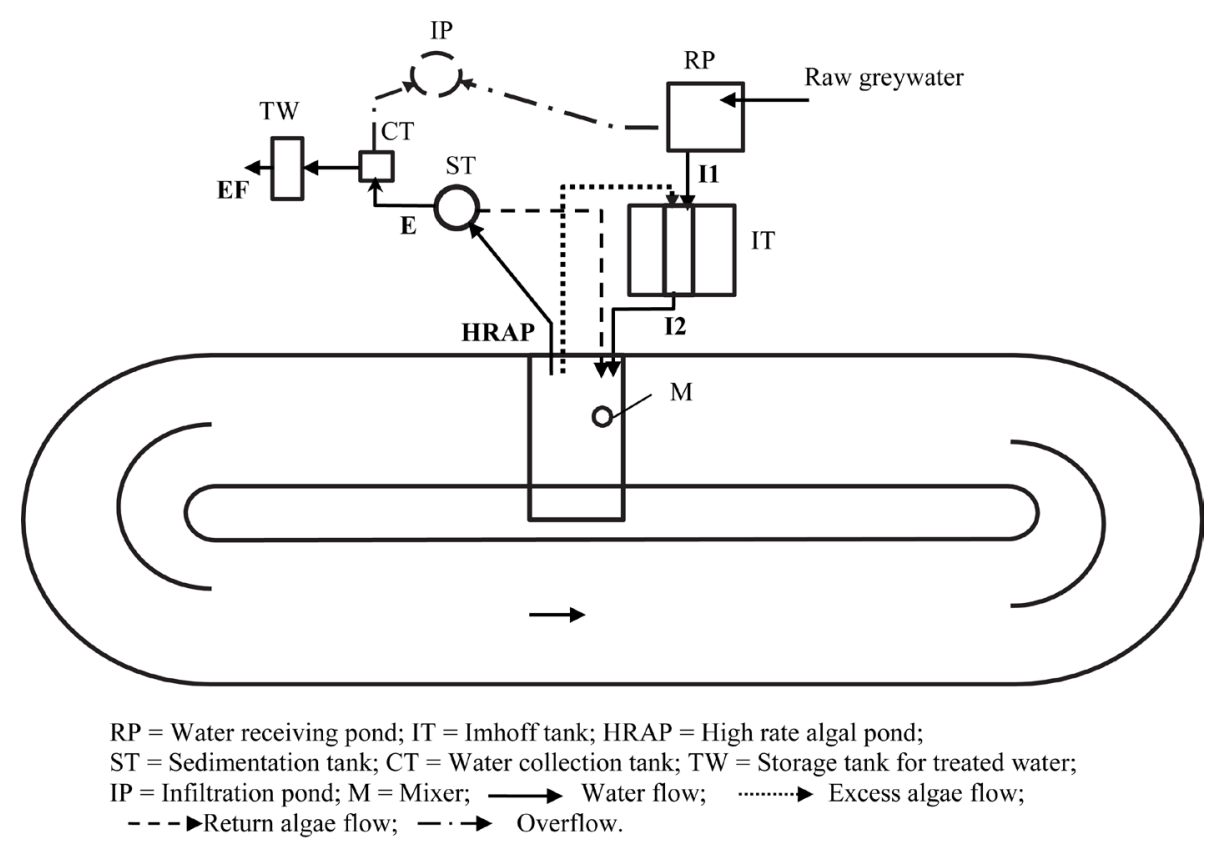

Figure 1. Top view of the greywater treatment unit showing the high rate algal pond, the associated ponds, the water flow directions and the sampling points.

Table 1. Characteristics and operational conditions of the HRAP.

\begin{tabular}{ccc}
\hline Characteristics & Size \\
\hline Water depth & $0.3 \mathrm{~m}$ \\
Length & $23.96 \mathrm{~m}$ \\
Width & $6.8 \mathrm{~m}$ \\
Length of linear channels & $17.16 \mathrm{~m}$ \\
Useful channel width (from top) & $1.8 \mathrm{~m}$ \\
Useful channel width (from bottom) & $1.2 \mathrm{~m}$ \\
$\begin{array}{c}\text { Effective diameter of the } \\
\text { semi-circular channels }\end{array}$ & $5.8 \mathrm{~m}$ \\
Surface area & External edge & $2.2 \mathrm{~m}$ \\
Effective volume & Internal edge & $84.4 \mathrm{~m}^{2}$ \\
Influent flow rate & $21.09 \mathrm{~m}^{3}$ \\
Excess algae flow rate & $2.8 \mathrm{~m}^{3} / \mathrm{day}$ \\
Return algae flow rate & $1.05 \mathrm{~m}^{3} / \mathrm{day}$ \\
Hydraulic retention time & $2.8 \mathrm{~m}^{3} / \mathrm{day}$ \\
Solid retention time & 7.5 days \\
\hline
\end{tabular}

entered the HRAP by gravity. Greywater circulation and homogenization in the HRAP was obtained using a mixer (M) (Satake Model A640 SATAKE chemical Equipment) rotating at a speed of 150 rpm. The hydraulic retention time was about 7.5 days. From the HRAP, greywater flowed to the Sedimentation tank (ST) by gravity. The algal biomass settled down in ST and the supernatant flowed by gravity into the water collection tank (CT). From CT, treated greywater was pumped to the Storage tank for treated water (TW) using an automatic pump (Master flex Model 07591-55). In order to select settleable algae and allow their growth in the HRAP, the algal biomass collected at the bottom of ST was removed using a peristaltic pump (Master flex Model 07591-55) at a 
flow of $2.8 \mathrm{~m}^{3} /$ day and recycled back to the HRAP (return algae). To avoid an overproduction of algae in the HRAP, greywater was pumped at mid depth from the HRAP and collected in the Imhoff tank using a peristaltic pump (Master flex Model 07591-55) at a flow of $1.05 \mathrm{~m}^{3} /$ day (excess algae). The solid retention time was estimated at 20 days. The experimental system was operated from the start-up in March 2013. Preliminary assays were conducted during the first 5 months in order to test the robustness of the system (clogging of pumps, optimization of hydraulic retention time, and appropriate rotation speed of the mixer). The present study presents the results obtained from October 2013 to April 2014 (7 months).

\subsection{Monitoring}

In order to assess the efficiency of the HRAP system, field measurements and water samples was taken once a week (9:00-10:00 am) to analyze fecal indicators, physico-chemical and organic parameters using influent of IT (I1), influent of HRAP (I2), the HRAP water (HRAP), effluent of ST (E) and the effluent from storage tank (EF). Temperature, $\mathrm{pH}$, dissolved oxygen (DO) and electrical conductivity (EC) were measured in situ using a portable electronic probe WTW multi 340i (WTW, GmbH, Weilheim, Germany). Chemical Oxygen Demand (COD), 5-days Biochemical Oxygen Demand $\left(\mathrm{BOD}_{5}\right.$ ), Suspended Solids (SS) were measured from homogenized samples to assess the removal efficiency of organic parameters. SS were determined by a gravimetric method using glass microfiber filters Whatman (porosity $1.5 \mu \mathrm{m}$ ). Nitrate, ammonia and orthophosphate were measured as nutrients by spectrophotometry, using filtered samples. Calcium, sodium and magnesium were determined in the treated water using atomic spectrophotometer (Perkin Elmer analyst 200). All analyses were performed according to Standard Methods for the Examination of Water and Wastewater [13]. Sodium adsorption ratio (SAR) was evaluated using the results from calcium, sodium and magnesium measurements "Equation (1)" to determine the suitability of the treated greywater for irrigation.

$$
\mathrm{SAR}=\frac{\mathrm{Na}^{+}}{\sqrt{\frac{\mathrm{Mg}^{2+}+\mathrm{Ca}^{2+}}{2}}}
$$

where $\mathrm{Na}^{+}, \mathrm{Ca}^{2+}$ and $\mathrm{Mg}^{2+}$ were expressed in milli-equivalents per litre (meq/L).

Escherichia coli, fecal coliforms and enterococci were monitored as indicator bacteria for microbiological pollution assessment. The spread plate method was used after an appropriate dilution of the samples in accordance with the procedure in Standard Methods [13]. Chromocult Coliform Agar (Merck KGaA 64271, Darmstadt, Germany) was used as the culture medium for both E. coli and fecal coliforms assessment whereas Slanetz and Bartley medium (Biokar Diagnostics, France) was used for enterococci assessment.

\subsection{Measurement of Algal Settling Efficiency}

Samples from HRAP water was collected once a week for the measurement of SS according to standard methods [13]. Algal settling efficiency (ASE) was measured once a week based on the method described by Park et al. [14]. A 1 liter imhoff cone was filled with HRAP water and left under laboratory conditions for sedimentation. To determine ASE (after 30 and 60 minutes), $50 \mathrm{ml}$ of water samples were taken after 30 and 60 minutes respectively, using a syringe from the top of the imhoff cone. SS were assessed in each sample and compared with the initial SS to determine $\mathrm{ASE}_{30}$ and $\mathrm{ASE}_{60}$ according to "Equation (2)".

$$
\operatorname{ASE}_{x}=\left[\frac{\left(S S_{i}-S S_{x}\right)}{S S_{i}}\right] \times 100
$$

with $S S_{i}=$ initial $S S ; S S_{x}=S S$ remaining in the supernatant after " $x$ " (30 or 60) minutes.

\section{Results and Discussion}

\subsection{Climatic Conditions of the Experimental Site}

The climatic data at the treatment plant $(12.46 \mathrm{~N}, 1.55 \mathrm{~W})$ were obtained from the NASA Amospheric Science Data Center (https://eosweb.larc.nasa.gov). The daily average (22-years average) solar radiation $\left(\mathrm{MJ} / \mathrm{m}^{2} /\right.$ day) and the minimum and maximum temperature for each month during the period of the study (October-April) are 
shown on Figure 2. December, January and February are marked by lower temperature and solar radiation. This period is the cold season in Burkina Faso which is marked by dusty weather that could have decreased the radiation reaching the earth. During the study period, the daily solar radiation was varying from 18.61 to 23.22 $\mathrm{MJ} / \mathrm{m}^{2} /$ day. The lowest solar radiation was registered in January while the highest value was obtained in April. The lowest minimum temperature $\left(16.3^{\circ} \mathrm{C}\right)$ was registered in January while the highest maximum temperature $\left(52.2^{\circ} \mathrm{C}\right)$ was obtained in March.

\subsection{Physico-Chemical Characteristics of the Raw Greywater}

The raw greywater produced at the students' residence was slightly polluted with organic matter when compared to data obtained in rural area in Burkina Faso. The values were varying from 14 to $88 \mathrm{mg} / \mathrm{L}$ for $S S, 65$ to 170 $\mathrm{mg} / \mathrm{L}$ for $\mathrm{BOD}_{5}$ and 145 to $958 \mathrm{mg} / \mathrm{L}$ for COD (Table 2). In rural area, for shower, laundry and dishwashing greywater, mean values of 1093 to $3060 \mathrm{mg} / \mathrm{L}, 533$ to $2743 \mathrm{mg} / \mathrm{L}$ and 1240 to $6497 \mathrm{mg} / \mathrm{L}$ have been reported for SS, $\mathrm{BOD}_{5}$ and COD respectively [15]. This situation could find an explanation in the effect of dilution due to the differences in amounts of water used to perform the activities. Indeed, greywater production in a household is directly influenced by water consumption which is dependent on a number of factors including the existing water supply service and infrastructure, the number of household members, the age distribution, the life style characteristics, the typical water usage patterns [16]. The authors highlighted that, in areas with water scarcity and rudimentary forms of water supply, water consumption varies from 20 to $30 \mathrm{~L} /$ capita/day whereas a household member in a richer area with piped water may generate several hundred liters per day [16]. Mean

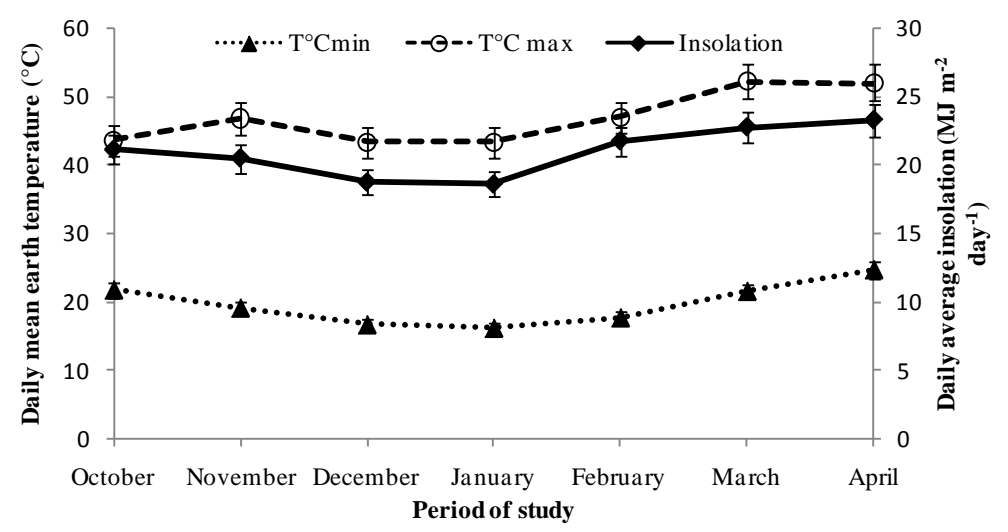

Figure 2. Mean monthly (22 years) temperature and solar radiation in the treatment plant Data obtained from NASA at: http://eosweb.larc.nasa.gov/cgi-bin/sse/grid.cgi. $\mathrm{T}^{\circ} \mathrm{C}$ min: minimum temperature; $\mathrm{T}^{\circ} \mathrm{C}$ max: maximum temperature.

Table 2. Characteristics of the raw greywater pumped from the water receiving pond.

\begin{tabular}{ccc}
\hline Parameter & Range & Average \pm SD \\
\hline Temperature $\left({ }^{\circ} \mathrm{C}\right)$ & $23.3-30.8$ & $27.13 \pm 2.25$ \\
$\mathrm{pH}$ & $6.29-7.54$ & $6.95 \pm 0.30$ \\
$\mathrm{EC}(\mu \mathrm{S} / \mathrm{cm})$ & $669-5620$ & $3677.05 \pm 1549.03$ \\
$\mathrm{SS}(\mathrm{mg} / \mathrm{L})$ & $14-88$ & $40.95 \pm 16.06$ \\
$\mathrm{BOD}_{5}(\mathrm{mg} / \mathrm{L})$ & $65-170$ & $109.25 \pm 27.21$ \\
$\mathrm{COD}(\mathrm{mg} / \mathrm{L})$ & $146-958$ & $464.4 \pm 252$ \\
$\mathrm{NH}_{4}^{+}(\mathrm{mg} / \mathrm{L})$ & $1.73-34.19$ & $22.55 \pm 11.63$ \\
$\mathrm{NO}_{3}^{-}(\mathrm{mg} / \mathrm{L})$ & $6.2-48.29$ & $21.52 \pm 10.9$ \\
$\mathrm{PO}_{4}^{3-} \quad(\mathrm{mg} / \mathrm{L})$ & $0.82-6.6$ & $3.36 \pm 1.58$ \\
\hline
\end{tabular}

$\mathrm{SD}=$ standard deviation; $\mathrm{EC}=$ electrical conductivity; $S S=$ suspended solids; $\mathrm{BOD}_{5}=5$ daysBiochemical oxygen demand; $\mathrm{COD}=$ Chemical oxygen demand. 
water consumption of 11 and $24 \mathrm{~L} /$ capita/day with a greywater production of 8 and $13 \mathrm{~L} / \mathrm{capita}$ /day have been reported in rural area in Burkina Faso [15] whereas water consumption in France was estimated at 150 L/capita/day.

\subsection{Evolution of the Physico-Chemical Parameters through the Pond System}

Figure 3(a) shows the distribution of the $\mathrm{pH}$ in the influent (I1), the HRAP (HRAP) and the effluent (EF). The $\mathrm{pH}$ of the influent greywater was varying from 6.29 to 7.54. In the HRAP, the $\mathrm{pH}$ increased to reach values varying between 7.38 and 9.46. Aguirre et al. [17] reported values of 7 to 8.2 in pilot HRAP treating pretreated piggery wastewater while Santiago et al. [18] reported mean $\mathrm{pH}$ values of $7.7 \pm 0.7$ and $8.1 \pm 1$ in HRAP treating non-disinfected and disinfected effluents from an upflow anaerobic sludge blanket respectively. Diurnal variation of $\mathrm{pH}$ has been reported in HRAP [10] [19] with maximum values reached between 1:00 pm and 3:00 pm [19]. Thus, the maximum $\mathrm{pH}$ of 9.46 reached in our HRAP, could be higher than this value, due to the fact that the measurements were performed in the morning (9:00 am-10: $00 \mathrm{am})$. The $\mathrm{pH}$ of the treated greywater is following the same trend as that of the HRAP water, however at a lower level (6.45 to 8.6).

Figure 3(b) shows the variation of the mean values of $\mathrm{pH}$, DO, temperature and EC through the treatment system. The $\mathrm{pH}$ and DO values are higher in the HRAP compared to that of the other ponds. This finding could be explained by the fact that $\mathrm{pH}$ and $\mathrm{DO}$ are variables associated with photosynthetic activity and that algal photosynthesis in HRAP can raise $\mathrm{pH}$ often exceeding $\mathrm{pH}>11$ [7]. Morning hours are marked by low DO values

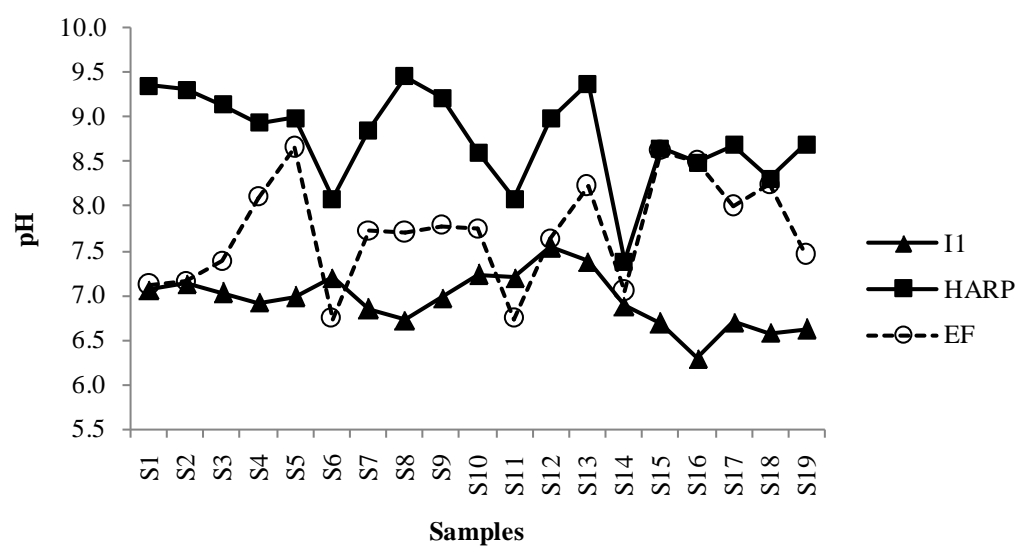

(a)

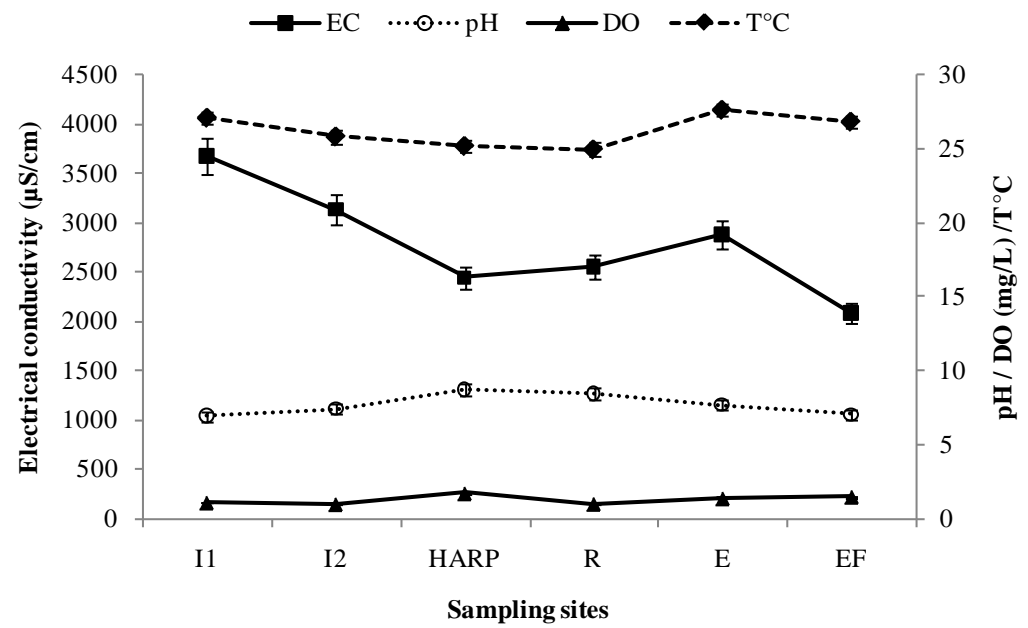

(b)

Figure 3. Variation of physico-chemical parameters. (a) Variation of $\mathrm{pH}$ in the influent (I1), the HRAP and the effluent (EF) during the study period; (b) Variation of mean values of $\mathrm{pH}, \mathrm{DO}$, temperature and $\mathrm{EC}$ through the pond system. 
compared to that of the afternoon, with maximum values reached between 1:00 pm and 3:00 pm [19]. In addition, Narcir et al. [10] reported diurnal variation of DO in HRAP with minimum values of $0.5 \mathrm{mg} / \mathrm{L}$. Therefore, the low values of DO in the HRAP compared to reported values is probably due to the fact that the sampling was conducted during the morning.

The EC values in the raw greywater were ranging from 669 to $5620 \mu \mathrm{S} / \mathrm{cm}$ for water temperature ranging from $23.3^{\circ} \mathrm{C}$ to $30.8^{\circ} \mathrm{C}$ (Table 2). As EC is varying with temperature, the trend of the later could explain the trend of EC in Figure 3(b).

\subsection{Distribution and Removal of Organic Compound}

Figures 4 (a)-(c) show respectively the variations of the concentrations of $\mathrm{SS}, \mathrm{BOD}_{5}$ and $\mathrm{COD}$ in the influent and the effluent of the pond system. In the influent, SS was varying from 14 to $88 \mathrm{mg} / \mathrm{L}, \mathrm{BOD}_{5}$ from 65 to 170 $\mathrm{mg} / \mathrm{L}$ and COD from 145 to $958 \mathrm{mg} / \mathrm{L}$ (Table 2).

The corresponding concentrations in the effluent were varying from 1 to $128 \mathrm{mg} / \mathrm{L}$ for $S S, 5$ to $70 \mathrm{mg} / \mathrm{L}$ for $\mathrm{BOD}_{5}$ and 54 to $366 \mathrm{mg} / \mathrm{L}$ for COD. The average removal efficiencies were $69 \%$ and $62 \%$ for $\mathrm{BOD}_{5}$ and COD respectively (Figure 4(d)). Narcir et al. [10], using a HRAP equipped with an air-lift have reported a removal efficiency of $44 \%$ for $\mathrm{BOD}_{5}$ while Chen et al. [20] have reported an annual removal efficiency of $50 \%$ for COD. In addition, El Hamouri et al. [21] have reported values of 65\% removal for BOD and COD under Moroccan climate. The shallow depth $(30 \mathrm{~cm})$ and the sunlight (Figure 2) contributed to enhance the algal productivity
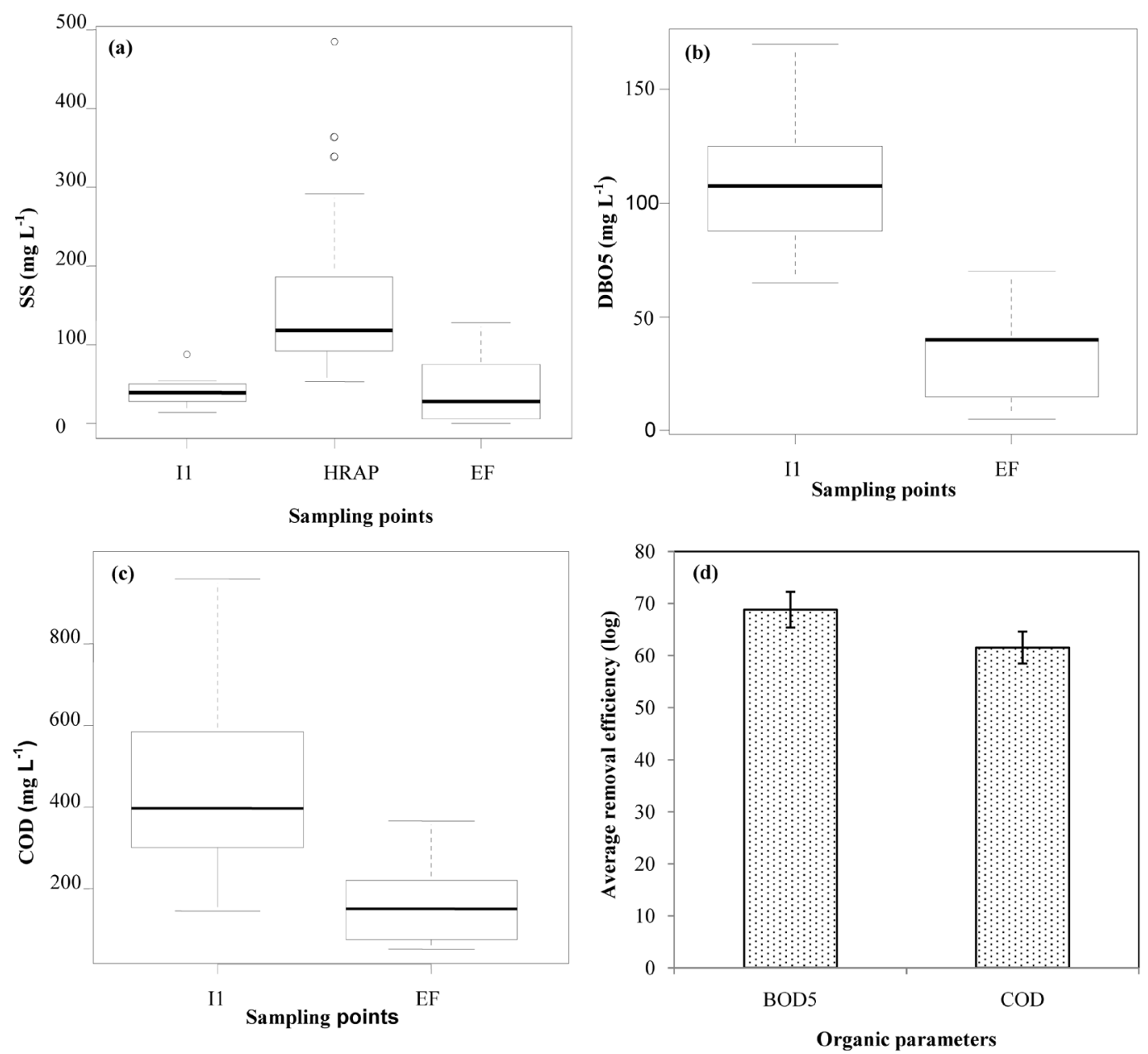

Figure 4. Variation of organic parameters $S S(\mathrm{a}), \mathrm{BOD}_{5}$ (b) and COD (c) through the treatment and the average removal efficiencies for BOD5 and COD (d) during the period of study. I1 = influent of imhoff tank (influent); $\mathrm{EF}=$ effluent of storage tank (treated greywater). 
and then, to increase $S S$ in the HRAP, with values varying from 53 to $484 \mathrm{mg} / \mathrm{L}$ (Figure 4(a)). Consequently, SS removal in the ST was unsatisfactory with values higher in the effluent compared to the influent in most of the cases. This finding is common in HRAP system. For instance, Chen et al. [20] reported that variables associated with photosynthetic activity such as DO, $\mathrm{pH}$ and $S S$ are significantly higher in the effluent compared to the influent.

\subsection{Nutrient Removal}

Nitrogen and phosphorus are important parameters given their fertilizing value for plant, their relevance for natural treatment processes and their potential negative impact on aquatic environment [16]. Figure 5(a) and Figure 5(b) show the variations in the concentrations of different forms of nutrients $\left(\mathrm{NO}_{3}^{-}, \mathrm{NH}_{4}^{+}\right.$and $\left.\mathrm{PO}_{4}^{3-}\right)$ in the influent and the effluent of the pond system and the corresponding removal efficiencies. The presence of phosphates and nitrates in greywater has been attributed to detergents and washing powders [16]. The nutrient content in the influent is in the range of reported values from Burkina Faso [15]. Nitrogen values are found within 6.3 and $48.29 \mathrm{mg} / \mathrm{L}$ for $\mathrm{NO}_{3}^{-}$and within 1.73 and 34.19 for $\mathrm{NH}_{4}^{+}$(Table 1; Figure 5). In addition, these values are in the range of typical values of nitrogen in mixed household greywater from different countries which are found within 5 to $50 \mathrm{mg} / \mathrm{L}$ [16]. The concentrations of $\mathrm{PO}_{4}^{3-}$ in the raw greywater are relatively low (Table 1). The relative use of phosphorus containing detergents and the dilution potential due to high water consumption could explain this finding.

The average removal efficiencies for nitrate and ammonia are 23\% and 52\% respectively (Figure 5(b)). Generally, the removal efficiency of ammonia by HRAP system is high. Chen et al. [20] and Narcir et al. [10] have reported removal efficiencies of $87 \%$ and up to $90 \%$ respectively. Furthermore, Aguirre et al. [17] have reported removal efficiencies varying from $68 \%$ to $85 \%$ for ammonia in a HRAP system treating piggery wastewater. However, El Hamouri et al. [21] have reported a low removal efficiency of $48 \%$ for ammonia under arid conditions. More recently, Derabe et al. [22] using artificial greywater at lab. scale have reported removal efficiencies of $20.07 \%$ and $53.39 \%$ for $\mathrm{NH}_{4}-\mathrm{N}$ in continuous and batch experiments respectively. The low removal efficiency of nitrate compared to ammonia in our study could be explained by the mechanisms involved in the removal process. Indeed, nitrate is mainly removed through algal uptake while ammonia is removed through stripping and algal uptake [23]. In addition, the same authors, dealing with nitrogen removal in HRAP systems, have reported that ammonia stripping was the most important mechanism for nitrogen removal followed by algal uptake and subsequent algal separation in the clarifiers. Furthermore, the low removal efficiency for nitrate despite the algae uptake could be attributed to the potential occurrence of nitrification during the process [20].

The average removal efficiency for orthophosphate is $43 \%$ (Figure 5(b)). Similar removal efficiencies of $40 \%$ [20] and 54\% have been reported [21]. Orthophosphate is removed through algal uptake allowing algal growth

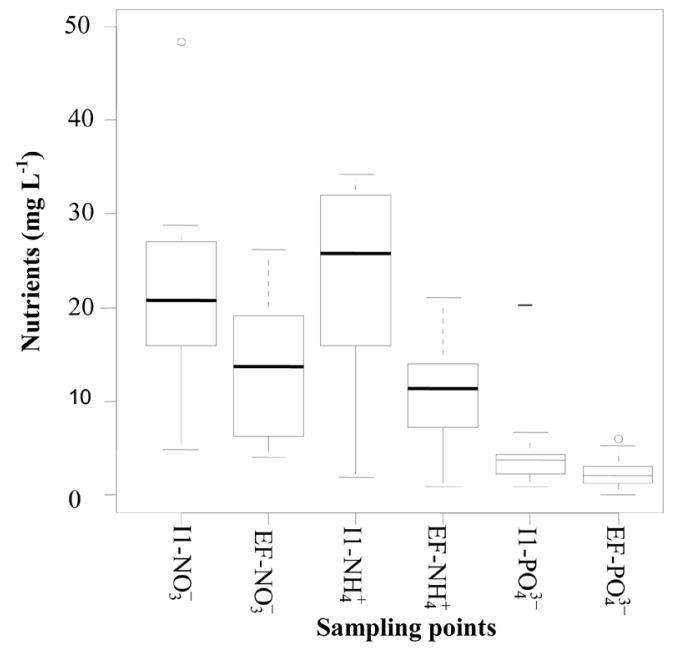

(a)

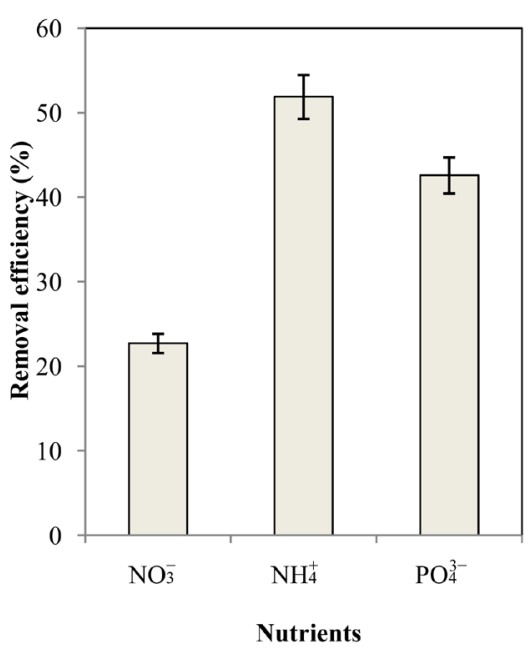

(b)

Figure 5. (a) Variation of concentration of nutrients $\left(\mathrm{NO}_{3}^{-}, \quad \mathrm{NH}_{4}^{+}, \quad \mathrm{PO}_{4}^{3-}\right)$ in the influent (I1) and the effluent (EF) and (b) the corresponding removal efficiencies. 
that in terns raises the $\mathrm{pH}$ of the mixed liquor, resulting in orthophosphate precipitation. The low concentration of orthophosphate in the influent (Table 1) could explain its low removal efficiency since phosphorus removal is positively linked to the influent phosphate concentration and the retention time [20].

\subsection{Distribution and Removal of Fecal Indicators}

During the study period, fecal bacteria content in the raw greywater pumped from the water receiving pond, varied from $2.60 \times 10^{4}$ to $1.59 \times 10^{5} \mathrm{CFU}$ per $100 \mathrm{~mL}$ for fecal coliforms, $6.67 \times 10^{2}$ to $6.27 \times 10^{4} \mathrm{CFU}$ per 100 $\mathrm{mL}$ for E. coli and from $2.33 \times 10^{3}$ to $1.73 \times 10^{5} \mathrm{CFU}$ per $100 \mathrm{~mL}$ for enterococci (Figure 6(a)). The mean values were $6.73 \times 10^{4} \mathrm{CFU}$ per $100 \mathrm{~mL}, 1.17 \times 10^{4} \mathrm{CFU}$ per $100 \mathrm{~mL}$ and $5.71 \times 10^{4} \mathrm{CFU}$ per $100 \mathrm{~mL}$ for fecal coliforms, E. coli and enterococci respectively. In terms of fecal bacteria content, the greywater produced in rural area in Burkina Faso is much more polluted than the greywater from the students' dormitory, used for the treatment. Indeed, values of up to $6 \times 10^{8} \mathrm{CFU}$ per $100 \mathrm{~mL}$ for $E$. coli and up to $1.63 \times 10^{9} \mathrm{CFU}$ per100 $\mathrm{mL}$ for fecal coliforms have been reported from a household in rural area [24]. The effect of the dilution due to the high amount of water used in urban area than rural area to perform the activities, could explain this difference.

The average removal efficiencies for the whole system were $2.65 \log$ units for fecal coliforms, $3.14 \log$ units for $E$. coli and $3.17 \log$ units for enterococci. The efficiency of the system is in the same range of reported values from previous studies. El Hamouri et al. [21] have reported a removal efficiency of 2.44 log units for fecal coliforms from the whole HRAP system treating wastewater. The HRAP component of the system, which operated under paddle wheel mixing contributed to a removal efficiency of 1.59 log units. More recently, removal efficiencies of $2.48 \log$ units for fecal coliforms and 2.62 log units for streptococci have been reported from a whole HRAP system treating wastewater in Morocco [10]. The contribution of the HRAP component operated by air-lift mixing was estimated to 1.43 and $1.47 \mathrm{log}$ units for fecal coliforms and streptococci respectively.

Previous studies showed that sunlight, $\mathrm{pH}$, protozoan grazing and reactive byproducts of oxygen such as superoxide anion radical, hydrogen peroxide and reactive hydroxyl radicals are factors involved in the inactivation of bacteria during the treatment [25]-[27]. Sunlight seems to be a major factor because of its high intensity (18.61 - $23.22 \mathrm{MJ} / \mathrm{m}^{2} /$ day) (Figure 2) and the low depth of the pond which allows its lower attenuation. Sunlight is detrimental to bacteria and beneficial to algal growth. UV-B $(280-320 \mathrm{~nm})$, UV-A $(320-400 \mathrm{~nm})$ and the Photosynthetically Available Radiation (PAR $>400 \mathrm{~nm}$ ) of the solar spectrum are responsible of inactivating bacteria [28]. Algal growth increased the $\mathrm{pH}$ (highest value of 9.46 from morning sampling) which is detrimental to bacteria. In this connection, Benchokroun et al. [26] have reported that $E$. coli was inactivated more rapidly when the $\mathrm{pH}$ was elevated above 8.5 than at lower $\mathrm{pH}$. In addition, algal growth promoted oxygen production

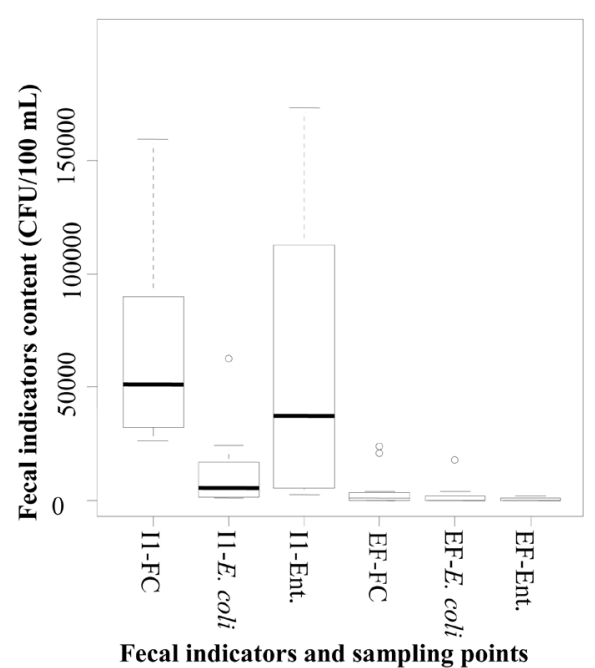

(a)

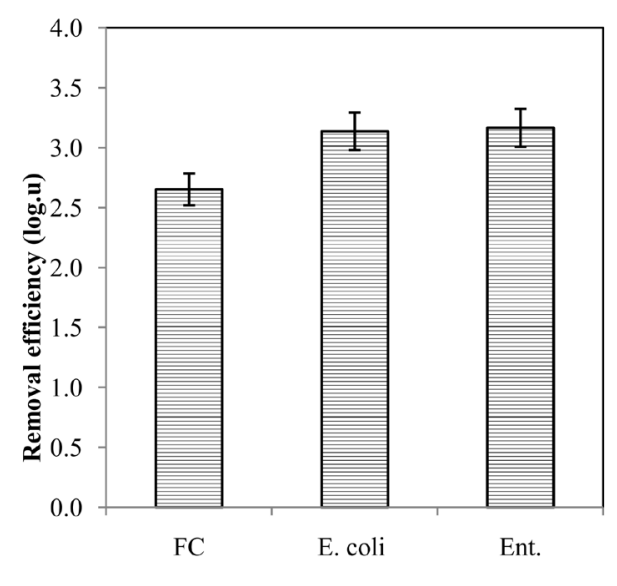

Fecal indicators

(b)

Figure 6. (a) Distribution of fecal indicators (FC, E. coli and Ent.) in the influent (I1) and the effluent (EF) and (b) the corresponding removal efficiencies. $\mathrm{FC}=$ fecal coliforms; Ent. = enterococci; $\log . \mathrm{u}=\log$ units. 
which is detrimental to fecal bacteria since it has been reported that survival of fecal coliforms in sunlight was completely dependent on the presence of oxygen and decreased with increasing oxygen concentration [26]. Molecular oxygen promotes solar photoinactivation mediated by endogenous photosensitizers [28]. As previously reported [27] [29], the results show that enterococci (Gram positive) (3.17 log units removal) were more affected that fecal coliforms (Gram negative) (2.65 log units removal). The difference in the characteristics of the bacterial cell wall was previously used to explain this finding [30]. The Gram negative bacterial (fecal coliform) cell wall lipopolysaccharide coat offers some protection from the toxic effects of exogenous agents.

\subsection{Algal Settling Efficiency}

Average algal settling efficiencies of $9.3 \% \pm 3.4 \%$ and $16.0 \% \pm 7.9 \%$ were achieved after 30 and 60 minutes of settling respectively. These low values of ASE corroborate with the unsatisfactory removal of SS. Park et al. [14] have reported ASE values of $86 \% \pm 9.1 \%$ and $93.6 \% \pm 2.8 \%$ after 30 and 60 minutes when Pediastrum sp. was present at over $80 \%$ dominance in the HRAP; ASE reduced to $25.6 \% \pm 10.2 \%$ and $35.2 \% \pm 10.1 \%$ when $P e$ diastrum sp. dominance declined to less than $40 \%$, for respective settling periods. Colonial algae settle faster than unicellular. Therefore, the characteristics of the algal species growing in the HRAP could explain the low ASE values. For this reason, further studies on the diversity and the identity of the algal species growing in the HRAP are necessary in order to enhance the settling efficiency. In addition, a previous study has reported that algal settling was promoted by calcium and orthophosphate concentrations in alkaline conditions (pH: 10 - 11) [31]. Therefore, the low pH values recorded in the HRAP (maximum value of 9.46) and the low concentration of orthophosphate in the influent could explain the low ASE values.

\subsection{Reuse Potential}

In the final effluent, the range of the concentration of E. coli was varying from less than 1 to $1.77 \times 10^{4} \mathrm{CFU}$ per $100 \mathrm{~mL}$ with a mean value of $1.96 \times 10^{3} \mathrm{CFU}$ per $100 \mathrm{~mL}$. The maximum values for fecal coliforms and enterococci were $2.37 \times 10^{4}$ and $1.67 \times 10^{3} \mathrm{CFU}$ per $100 \mathrm{~mL}$ respectively; their mean values were $3.98 \times 10^{3}$ and $5.12 \times 10^{2} \mathrm{CFU}$ per $100 \mathrm{~mL}$ respectively. Based on the WHO guidelines for greywater reuse in restricted (E. coli $<10^{5} \mathrm{CFU}$ per $100 \mathrm{~mL}$ ) and unrestricted irrigation (E. coli $<10^{3} \mathrm{CFU}$ per $100 \mathrm{~mL}$ ) [32], the final effluent could be used for restricted irrigation.

$\mathrm{pH}$ is also an important environmental parameter to consider when greywater is intended for reuse in irrigation. The treated greywater was characterized by $\mathrm{pH}$ values varying from 6.45 to 8.6 which can have beneficial effect on the bacteria of the irrigated soil, since most bacteria prefer neutral or slightly alkaline conditions, around 6.5 - 8.5 [33]. In turn, bacterial growth can promote irrigated vegetables development by increasing nutrients availability from organic matter.

The concentrations of nutrients found in the effluents $(3.99-26.14 \mathrm{mg} / \mathrm{L}$ for nitrate, $0.71-21.03 \mathrm{mg} / \mathrm{L}$ for ammonia, 0.07 - $6 \mathrm{mg} / \mathrm{L}$ for orthophosphate) can be beneficial for irrigated vegetables, since nitrogen and phosphorus are essential plant nutrient. However, greywater rich in nitrate can have a negative impact as nitrate is highly soluble and can move easily in soils irrigated with wastewater [1].

The electrical conductivity (EC) values of the treated greywater varied from 482 and $4500 \mu \mathrm{S} / \mathrm{cm}$. High EC in irrigated water can result in an increase in osmotic potential in the soil solution and interfere with extraction of water by plants [1]. Permissible EC for greywater reuse in irrigation are strongly dependent on soil characteristics and the suggested limits differ in the literature reviewed [16]. According to WHO [32] guidelines, the recommended maximum value for greywater reuse in irrigation is $3000 \mu \mathrm{S} / \mathrm{cm}$. Grattan [34] reported that EC below $1300 \mu \mathrm{S} / \mathrm{cm}$ should normally not cause problems whereas irrigation with saline greywater (EC exceeding $1300 \mu \mathrm{S} / \mathrm{cm}$ ) requires special precautions (use of salt-tolerant plants). According to FAO [35], water with EC varying from 700 to $3000 \mu \mathrm{S} / \mathrm{cm}$ and EC exceeding $3000 \mu \mathrm{S} / \mathrm{cm}$ are considered as "slight to moderate" and "severe degree of restriction on use" respectively. Therefore, the treated greywater is classified between "slight to moderate" and "severe degree of restriction on use" based on FAO guidelines.

In addition, it has been reported that the effect of sodium ions in irrigation water is dependent on the total salt concentration and the sodium ions concentration relative to the concentration of calcium and magnesium ions (as indicated by SAR) [35]. The SAR values of the treated greywater were varying between 3.03 and 4.11 (Table 3). Thus, for surface irrigation, when we consider specific sodium toxicity, the treated greywater is classified as "slight to moderate degree of restriction on use" according to FAO guidelines [35]. 
Table 3. Range of the concentrations of $\mathrm{Ca}^{2+}, \mathrm{Mg}^{2+}, \mathrm{Na}^{+}$and the corresponding SAR values of the treated greywater.

\begin{tabular}{ccc}
\hline Parameters & Minimum & Maximum \\
\hline Calcium (mg/L) & 5.89 & 7.21 \\
Magnesium (mg/L) & 2.73 & 5.73 \\
Sodium (mg/L) & 22.74 & 24.99 \\
SAR & 3.03 & 4.11 \\
\hline
\end{tabular}

SAR $=$ Sodium Adsorption Ratio.

Furthermore, it has been reported that for a given SAR value, an increase in total salt concentration (EC) is likely to increase soil permeability and, for a given total salt concentration, an increase in SAR will decrease soil permeability. Irrigation water with SAR values of 3 to 6 and EC exceeding $1200 \mu \mathrm{S} / \mathrm{cm}$ is considered as "none degree of restriction on use" [35]. Therefore, the possible effect of the high EC values of the treated greywater can be moderated by the SAR values.

\section{Conclusions}

This study demonstrated that High Rate Algal Pond technique could be suitable for greywater treatment under climatic conditions of Ouagadougou (Burkina Faso). The mean removal efficiencies were $69 \%$ and $62 \%$ for $\mathrm{BOD}_{5}$ and COD respectively. The average removal efficiencies for $\mathrm{NO}_{3}^{-}, \mathrm{NH}_{4}^{+}$and $\mathrm{PO}_{4}^{3-}$ were 23\%, 52\% and $43 \%$ respectively. The relative low removal of nutrients compared to previous studies could be beneficial since the effluents are intended for reuse in gardening, the residual nutrients, being important for vegetables.

The whole treatment system allowed average removal efficiencies of $2.65 \log$ units for fecal coliforms, 3.14 $\log$ units for $E$. coli and $3.17 \log$ units for enterococci. The residual content of $E$. coli was varying from $<1$ to $1.77 \times 10^{4} \mathrm{CFU}$ per $100 \mathrm{~mL}$ with a mean value of $1.96 \times 10^{3} \mathrm{CFU}$ per $100 \mathrm{~mL}$. Based on the WHO guidelines for greywater reuse in restricted $\left(E\right.$. coli $<10^{5} \mathrm{CFU}$ per $\left.100 \mathrm{~mL}\right)$ and unrestricted irrigation $\left(\right.$ E. coli $<10^{3} \mathrm{CFU}$ per $100 \mathrm{~mL}$ ), the final effluent could be used for restricted irrigation. The $\mathrm{pH}$ values of the effluent were in compliance with the recommended values for irrigation. The EC values of the treated greywater were high, sometimes over the recommended values of $3000 \mu \mathrm{S} / \mathrm{cm}$. However, the effect of these high values on the irrigated soil can be moderated by the SAR values.

Low average algal settling efficiencies of $9.3 \% \pm 3.4 \%$ and $16.0 \% \pm 7.9 \%$ were achieved after 30 and 60 minutes of settling respectively, which could explain the unsatisfactory removal of SS. To increase the settleability of algae, and then SS removal, further studies on the algal species involved are necessary.

\section{Acknowledgements}

The authors thank Japan International Cooperation Agency (JICA) for providing the funds.

\section{References}

[1] International Water Management Institute (IWMI) (2010) Wastewater Irrigation and Health: Assessing and Mitigating Risk in Low-Income Countries. Earthscan, London.

[2] Kêdowidé, C.M.G., Sedogo, M.P. and Cissé, G. (2010) Dynamique spatio temporelle de l'agriculture urbaine à Ouagadougou: Cas du Maraîchage comme une activité montante de stratégie de survie. Vertigo—La Revue Electronique en Sciences de l'Environnement, 10, [En Ligne]. http://vertigo.revues.org/10312

[3] Friedle, R.E. and Hadari, M. (2006) Economic Feasibility of On-Site Greywater Reuse in Multi-Storey Building. Desalination, 190, 221-234. http://gwri.technion.ac.il/pdf/gwri_abstracts/2006/57.pdf http://dx.doi.org/10.1016/j.desal.2005.10.007

[4] Winward, G.P., Avery, L.M., Frazer-Williams, R., Pidou, M., Jeffrey, P., Stephenson, T. and Jefferson, B. (2008) A Study of the Microbial Quality of Greywater and an Evaluation of Treatment Technologies for Reuse. Ecological Engineering, 32, 187-197. http://www.sciencedirect.com/science/article/pii/S092585740700211X http://dx.doi.org/10.1016/j.ecoleng.2007.11.001

[5] Tarchitzky, J., Lerner, O., Shani, U., Arye, G., Lowengart-Aycicegi, A., Brener, A. and Chen, Y. (2007) Water Distri- 
bution Pattern in Treated Wastewater Irrigated Soils: Hydrophobicity Effect. European Journal of Soil Science, 58, 573-588. http://onlinelibrary.wiley.com/doi/10.1111/j.1365-2389.2006.00845.x/abstract http://dx.doi.org/10.1111/j.1365-2389.2006.00845.x

[6] Travis, M.J., Wiel-Shafran, A., Weisbrod, N., Adar, E. and Gross, A. (2010) Greywater Reuse for Irrigation: Effect on Soil Properties. Science of the Total Environment, 408, 2501-2508. http://www.sciencedirect.com/science/article/pii/S0048969710002524 http://dx.doi.org/10.1016/j.scitotenv.2010.03.005

[7] Park, J.B.K. and Craggs, R.J. (2010) Wastewater Treatment and Algal Production in High Rate Algal Ponds with Carbon Dioxide Addition. Water Science and Technology, 63, 633-639. http://www.ncbi.nlm.nih.gov/pubmed/20150699 http://dx.doi.org/10.2166/wst.2010.951

[8] Craggs, R.J., Heubeck, S., Lundquist, T.J. and Benemann, J.R. (2011) Algae Biofuel from Wastewater Treatment High Rate Algal Ponds. Water Science and Technology, 63, 660-665. http://www.ncbi.nlm.nih.gov/pubmed/21330711 http://dx.doi.org/10.2166/wst.2011.100

[9] Sukias, J.P.S. and Craggs, R.J. (2011) Digestion of Wastewater Pond Microalgae and Inhibition from Ammonium and Alum. Water Science and Technology, 63, 835-840. http://www.ncbi.nlm.nih.gov/pubmed/21411930 http://dx.doi.org/10.2166/wst.2011.101

[10] Nacir, S., Ouazzani, N., Vasel, J.L., Jupsin, H. and Mandi, L. (2010) Traitement des eaux usées domestiques par un chénal algal à haut rendement (CAHR) agité par air lift sous climat semi-aride. Revue des sciences de l'eau/Journal of Water Science, 23, 57-72. http://www.erudit.org/revue/rseau/2010/v23/n1/038925ar.html?vue=resume

[11] Park, J.B.K., Craggs, R.J. and Shilton, A.N. (2011) Wastewater Treatment High Rate Algal Ponds for Biofuel Production. Bioresource Technology, 102, 35-42. http://www.sciencedirect.com/science/article/pii/S0960852410011636 http://dx.doi.org/10.1016/j.biortech.2010.06.158

[12] Kenfack, S. (2006) Helio-Photocatalytic Enhancement of the Biodegradation of Biorecalcitrant Pollutants in Water: Physicochemical and Technical Aspects. PhD Thesis, EPFL, Lausanne.

[13] American Public Health Association (APHA), American Water Works Association (AWWA) and Water Environment Federation (WEF) (1998) Standard Methods for the Examination of Water and Wastewater. 20th Edition, APHA/ AWWA/WEF, Washington DC.

[14] Park, J.B.K., Craggs, R.J. and Shilton, A.N. (2011) Recycling Algae to Improve Species Control and Harvest Efficiency from a High Rate Algal Pond. Water Research, 45, 6637-6648. http://www.sciencedirect.com/science/article/pii/S0043135411005720

[15] Maiga, Y., Moyenga, D., Ushijima, K., Sou, M. and Maiga, A.H. (2014) Greywater Characteristics in Rural Areas of Sahelian Region for Reuse Purposes: The Case of Burkina Faso. Revue des sciences de l'eau/Journal of Water Science, 27, 39-54. www.erudit.org/revue/rseau/2014/v27/n1/1021981ar.html?vue=resume\&modes=restriction.

[16] Morel, A. and Diener, S. (2006) Greywater Management in Low and Middle-Income Countries, Review of Different Treatment Systems for Households and Neighborhood. Swiss Federal Institute of Aquatic Science and Technology (Eawag), SANDEC, Dübendorf.

[17] Aguirre, P., Alvarez, E., Ferrer, I. and Garcia, J. (2011) Treatment of Piggery Wastewater in Experimental High Rate Algal Ponds. Revista Latinoamericana de Biotecnologia Ambiental y Algal, 2, 57-66. http://uniciencia.ambientalex.info/revistas/vol2n21.pdf

[18] Santiago, A.N., Calijuri, M.L., Assemany, P.P., Calijuri, M.C. and dos Reis, A.J.D. (2013) Algal Biomass Production and Wastewater Treatment in High Rate Algal Ponds Receiving Disinfected Effluent. Environmental Technology, 34, 1877-1885. http://dx.doi.org/10.1080/09593330.2013.812670

[19] Picot, B., Moersidik, S., Casellas, C. and Bontoux, J. (1993) Using Diurnal Variations in a High Rate Algal Pond for Management Pattern. Water Science and Technology, 28, 169-175. http://www.iwaponline.com/wst/02810/wst028100169.htm

[20] Chen, P., Zhou, Q., Paing, J., Le, H. and Picot, B. (2003) Nutrient Removal by the Integrated Use of High Rate Algal Ponds and Macrophyte Systems in China. Water Science and Technology, 48, 251-257. http://www.ncbi.nlm.nih.gov/pubmed/14510218

[21] El Hamouri, B., Rami, A. and Vasel, J.L. (2003) The Reasons behind the Performance Superiority of a High Rate Algal Pond over Three Facultative Ponds in Series. Water Science and Technology, 48, 269-276. http://www.ncbi.nlm.nih.gov/pubmed/14510220.

[22] Derabe, H.M., Onodera, M., Takahashi, M., Satoh, H. and Fukazawa, T. (2014) Control of Algal Production in a High Rate Algal Pond: Investigation through Batch and Continuous Experiments. Water Science and Technology, 69, 25192525. http://www.ncbi.nlm.nih.gov/pubmed/24960016 
http://dx.doi.org/10.2166/wst.2014.174

[23] García, J., Mujeriego, R. and Hernández-Mariné, M. (2000) High Rate Algal Ponds Operating Strategies for Urban Wastewater Nitrogen Removal. Journal of Applied Phycology, 12, 331-339. http://link.springer.com/article/10.1023\%2FA\%3A1008146421368 http://dx.doi.org/10.1023/A:1008146421368

[24] Maiga, Y., Moyenga, D., Nikiema, B.C., Ushijima, K., Maiga, A.H. and Funamizu, N. (2014) Designing Slanted Soil System for Greywater Treatment for Irrigation Purposes in Rural Area of Arid Regions. Environmental Technology, 35, 3020-3027. http://dx.doi.org/10.1080/09593330.2014.929180 http://dx.doi.org/10.1080/09593330.2014.929180

[25] Arana, I., Irizar, A., Seco, C., Muela, A., Fernández-Astorga, A. and Barcina, I. (2003) gfp-Tagged Cells as a Useful Tool to Study the Survival of Escherichia coli in the Presence of the River Microbial Community. Microbial Ecology, 45, 29-38. http://www.ncbi.nlm.nih.gov/pubmed/12447583 http://dx.doi.org/10.1007/s00248-002-1029-9

[26] Benchokroun, S., Imziln, B. and Hassani, L. (2003) Solar Inactivation of Mesophilic Aeromonas by Exogenous Photooxidation in High-Rate Algal Pond Treating Wastewater. Journal of Applied Microbiology, 94, 531-538. http://www.ncbi.nlm.nih.gov/pubmed/12588563 http://dx.doi.org/10.1046/j.1365-2672.2003.01867.x

[27] Maiga, Y., Wethe, J., Denyigba, K. and Ouattara, A.S. (2009) The Impact of Pond Depth and Environmental Conditions on Sunlight Inactivation of E. coli and Enterococci in Wastewater in a Warm Climate. Canadian Journal of Microbiology, 55, 1364-1374. http://www.ncbi.nlm.nih.gov/pubmed/20029528 http://dx.doi.org/10.1139/W09-104

[28] Muela, A., Garcia-Bringas, J.M., Seco, C., Arana, I. and Barcina, I. (2002) Participation of Oxygen and Role of Exogenous and Endogenous Sensitizers in the Photoinactivation of Escherichia coli by Photosynthetically Active Radiation, UV-A and UV-B. Microbial Ecology, 44, 354-364. http://www.ncbi.nlm.nih.gov/pubmed/12375094 http://dx.doi.org/10.1007/s00248-002-1027-y

[29] Anderson, K.L., Whitlock, J.E. and Harwood, V.J. (2005) Persistence and Differential Survival of Fecal Bacteria in Subtropical Waters and Sediments. Applied and Environmental Microbiology, 71, 3041-3048. http://www.ncbi.nlm.nih.gov/pmc/articles/PMC1151827/pdf/1861-04.pdf http://dx.doi.org/10.1128/AEM.71.6.3041-3048.2005

[30] Jori, G. and Brown, S.B. (2004) Photosensitized Inactivation of Microorganisms. Photochemical \& Photobiological Sciences, 3, 403-405. http://www.ncbi.nlm.nih.gov/pubmed/15122355 http://dx.doi.org/10.1039/b311904c

[31] Baya, D.G.S.T. (2012) Etude de l'autofloculation dans un chénal algal à haut rendement. Thèse de Doctorat, Université de Liège, Liège. (In French)

[32] WHO (2006) Guidelines for the Safe Use of Wastewater, Excreta and Greywater, Volume 4: Excreta and Greywater Use in Agriculture. WHO Press, Geneva.

[33] Mara, D. (2004) Domestic Wastewater Treatment in Developing Countries. Earthscan, London.

[34] Grattan, S.R. (2002) Irrigation Water Salinity and Crop Production. Publication 8066, University of California, Oakland. http://vric.ucdavis.edu/pdf/Irrigation/IrrigationWaterSalinityandCropProduction.pdf

[35] Food and Agriculture Organization of the United Nations (1985) Water quality for agriculture. FAO, Rome. http://www.fao.org/DOCReP/003/T0234e/T0234e00.htm 